\title{
Efficacy of parasitological diagnosis methods in wild animals kept in captivity
}

\author{
Eficácia dos métodos de diagnóstico parasitológico em animais silvestres \\ mantidos em cativeiro
}

\author{
Aline Feola Carvalho ${ }^{1}$, Anderson Sena Barnabe ${ }^{1 *}$, Igor Popovic Federsoni ${ }^{1}$, Renato Ribeiro Nogueira \\ Ferraz'1, Rogerio Milton De Marco', Isabel Priscilla Garcia'
}

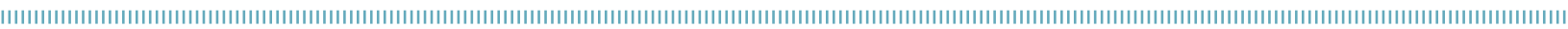

\begin{abstract}
Parasitic diseases are common in wild animals kept in captivity, and the research of these parasites is a tool used in wildlife management actions. Once the method most used in the practice of veterinary laboratories is the direct examination, it was considered appropriate to report the parasitism in captivity wildlife comparing this technique with modified methods of Hoffman, Pons and Janer (HPJ) and Willis. Fresh feces were surveyed in eleven precincts with specimens of the class Reptilia, Birds and Mammalia. A positive result for the presence of parasites was observed in $81.8 \%$ of them, of which $18.2 \%$ were, $9.1 \%$ helminths and $54.6 \%$ protozoa and helminths simultaneously. The direct and HPJ methods were more specific for the identification of parasites, 72.7 and $63.6 \%$, respectively, while the method of Willis showed less positive results $(36.4 \%)$. It is concluded that the ideal routine in veterinary laboratory fecal examinations of wild animals is to use the HPJ method associated with the direct method for the detection of protozoa and/or helminths, in order to obtain more accurate results.
\end{abstract}

KEYWORDS: wild animals; intestinal endoparasites; diagnostic methods.
RESUMO: As enfermidades parasitárias são comumente encontradas em animais silvestres mantidos em cativeiro, e a pesquisa desses parasitas é uma ferramenta utilizada em açóes de manejo de fauna. Uma vez que o método mais utilizado na prática dos laboratórios veterinários é o exame direto, diante disto, considerou-se oportuno relatar o parasitismo em silvestres de cativeiro comparando esta técnica com os métodos de Hoffman, Pons e Janer (HPJ) modificado e de Willis. Foram pesquisadas fezes frescas de onze recintos com espécimes das classes Reptilia, Aves e Mammalia, sendo que $81,8 \%$ foram positivas para a presença de parasitas em que $18,2 \%$ apresentavam protozoários em suas fezes, 9,1\% helmintos e 54,6\% protozoários e helmintos simultaneamente. $\mathrm{O}$ método direto e de HPJ foram mais específicos para identificação de parasitas, 72,7 e $63,6 \%$, respectivamente, enquanto que o método de Willis apresentou menor positividade $(36,4 \%)$. Conclui-se que o ideal na rotina laboratorial veterinária para exames coproparasitológicos de animais silvestres é a utilização do método HPJ associado ao método direto para detecçáo de protozoários e/ou helmintos, visando obter resultados mais precisos.

PALAVRAS-CHAVE: animais silvestres; endoparasitas intestinais; métodos diagnósticos. 
Parasitic infections still pose a major public and animal health problem. The emergence and re-emergence of infectious parasitic diseases is a frequent concern of health surveillance services, and epidemiological studies are developed to assess the frequency of parasitism in domestic and wild animals (BUNBURY et al., 2008).

In the present study, wild animals are kept in captivity, which may cause variations in parasitic infections related to environment, demographics, behavior and anthropic actions these animals are subjected to in captivity (STUART et al., 1993; SANTOS, 2005).

It is of great relevance to perform laboratory tests in wild animals, since many of the parasites harboring them are zoonoses agents (STUART et al., 1993). Therefore, knowledge of intestinal parasitic diseases is important both for animal welfare and for adopting control measures in animal and animal health (STUART et al., 1993).

The identification of parasites in feces is routinely performed by various diagnostic techniques (BATISTA et al., 2012). This diagnosis should aim at high sensitivity (correct diagnosis in relation to the truly infected animals), since the specific treatment of the animal depends on these conditions (BRANDÁO et al., 2009).

Even in the presence of numerous quantitative and qualitative methods of coproparasitological diagnoses, many are still criticized for their limitations, technical complexity, low sensitivity and high cost of execution, restricting their use in the routine of some laboratories (BRANDÁO et al., 2009). In laboratory practice, using more than one method to detect immature forms of helminths or protozoa would be ideal, aiming to reduce results of low accuracy, since there are important variations in the positivity of fecal examination, significantly influencing the detection of infection, such as loading (HUGGINS et al., 1998). In addition to these factors, SUDRÉ et al. (2006) conclude that no test is considered $100 \%$ sensitive for diagnosis. A single stool specimen examined for parasitological investigation leads to the detection of about $30 \%$ of infections. The sensitivity of the diagnosis increases to about $50 \%$ if three fecal samples are used, and may reach close to $100 \%$ with the use of seven samples, which often becomes time-consuming and costly (SUDRÉ et al., 2006).

In a brief bibliographical survey, the idea of increasing diagnostic sensitivity evidenced in the comparison of methods in the comparative studies of four different methods for the examination of fecal samples (direct examination, formalin-ethyl acetate, Harada-Mori and agar plate culture) by SATO et al. (1995), higher sensitivity was detected when the techniques were associated in relation to the agar plate culture method. The same result was corroborated by KOBAYASHI et al. (1996), in which about $60 \%$ of the cases would not have been diagnosed if only the Harada-Mori and fecal concentration methods had been used. Therefore, it is necessary to conjugate methods and to analyze their diagnostic sensitivities so that we have action applicability in the secondary prevention measures of parasitic diseases in animals and a better epidemiological profile of these diseases.

In the practice of veterinary parasitic diagnostic laboratories, few adaptations are made in relation to human fecal exams, and with fresh direct examination as one of the most common procedure (SATO et al., 1995; KOBAYASHI et al., 1996), it was considered opportune to evaluate the degree of diagnostic sensitivity of this technique compared with the direct methods of WILLIS (1921) and the Hoffman, Pons and Janer (HPJ) (HOFFMAN et al., 1934) or Lutz technique, which have already been used in other epidemiological studies of parasitic veterinary infections (BUNBURY et al., 2008; STUART et al., 1993; SANTOS, 2005).

Fecal samples were collected from wild animals kept in captivity. These animals belong to the Wildlife Supporter Antonio de Pádua Tortorello - Bioparque Macuco, located in Mauá, São Paulo, Brazil, in 2015.

Feces samples were collected in a non-invasive manner directly from the enclosure immediately after the animal's defecation, stored in a sterile universal collector, immediately identified and stored under refrigeration at 3 to $5^{\circ} \mathrm{C}$. Fresh stool analysis was performed within 24 hours after harvest, in the Mantenedouro's own laboratory following the guidelines of DE CARLI (2007).

In total, eleven samples of fresh feces were collected from specimens of Reptilia: jabuti-pirangaChelonoidis carbonária Spix, 1824 (Reptilia: Testudinidae); of Birds: coruja-orelhuda Asio clamator Vieillot, 1808 (Bird: Asioninae), corujinha-domato Megascops choliba Vieillot, 1817 (Bird: Strigidae) and tucano-de-bico-verde Ramphastos dicolorus Linnaeus, 1766 (Bird: Ramphastidae); and of Mammalia: furão Galictis cuja Molina, 1782 (Mammalia: Musteloidea), gambá Didelphis marsupialis Linnaeus, 1758 (Mammalia: Didelphinae), quati Nasua nasua Linnaeus, 1766 (Mammalia: Procyonidae), tapiti Sylvilagus brasiliensis Linnaeus, 1758 (Mammalia: Leporidae), bugio Alouatta fusca Cabrera, 1940 (Mammalia: Atelidae), macaco-prego Sapajus apela Linnaeus, 1758 (Mammalia: Cebidae) and sagui-de-tufo-branco Callithrix jacchus Erxleben, 1777 (Mammalia: Callitrichinae).

In the preanalytical phase, the direct examination of the samples from the fresh stool was carried out by using the direct method of observation under microscopy of the feces with a dilution of $1 \mathrm{~mL}$ of saline solution between the slide and cover slip; the Willis method, which consists of the process of fluctuating a portion of stool diluted in hypersaturated saline solution with resting of the slides for 5 minutes, conditioned in a petri dish; and the technique of spontaneous sedimentation known as HPJ technique, which analyzes the sediment of diluted feces and coiled, allowed to rest in a sediment cone for 24 hours (DE CARLI, 2007).

From the performance of each technique, three slides were prepared, stained with lugol and observed under an optical microscope (DE CARLI, 2007).

The evaluation of the parasitic load was based on the classification of PINTO et al. (1994), which considered infections as: mild (1-100 cysts or oocysts/slide), moderate (101300 ), and elevated (more than 301 cysts or oocysts/slide). For helminths, classes I (1-20 eggs/slide), II (21-40), III (41-60), IV (61-80), V (81-100) and VI (+100/slide). 
The prevalence and parasite density were analyzed from the results of cysts or egg counts according to FERRAZ et al. (2014), adding a graphic analysis methodology proposed by Bland and Altman (Bland-Altman graphical analysis) to evaluate the agreement between the methods and the differences between parasite counts obtained with the three types of tests plotted against the averages of both values (BLAND; ALTMAN, 1986). The limits of this agreement are contained in the interval between the mean difference observed between both methods $\pm 1.96 \mathrm{SD}$.

Prevalence was defined as the number of hosts infected by a parasite species. The Shapiro-Wilk normality test was used to evaluate the distribution of data between parasite loads of helminths and protozoa using the Sigma Stat program version 3.5 , as well as the analysis of variance (two factors) between parasite load and class of animals, adopting a $5 \% \alpha$.

The analysis of the diagnostic sensitivity between the techniques and in a combined way followed the accuracy parameters seen in FLETCHER et al. (2003).

Parasitic diseases are commonly found in wild animals kept in captivity, and the research of these parasites can be a tool to study the health status of the population and the environment, as well as be used in wildlife management actions (CATENACCI et al., 2004).

Coproparasitological examinations of samples from 11 sites were performed. From the total samples collected, $81.8 \%$ $(9 / 11)$ were positive for the presence of parasites, 2 out of 11 (18.2\%) had protozoa in their feces, 1 out of $11(9.1 \%)$ had helminths and 6/11 (54.6\%) had both protozoa and helminths, simultaneously.

From the Reptilia class, it was identified in the jabutipiranga (C. carbonaria) cysts of Balantidium testudinis by the direct and HPJ methods and Platynosomum sp. by HPJ.

In relation to birds, the owl-eared owl (A. clamator) presented egg of Toxocara sp. and Ascaris sp. diagnosed by the direct method, eggs of Raillietina sp. by the HPJ method, and Isospora sp. oocysts in both techniques.

The black owl (M. choliba) obtained negative results for intestinal parasites in the three methods used.

The green-beaked toucan ( $R$. dicolorus) presented oocysts of Eimeria sp. $(1,125$ oocysts/slide) in the three techniques performed.

Regarding the Mammalia class, G. of which Ascaris sp. by the direct method; larva of Strongyloididae by HPJ, and cysts of Balantidium sp. by the Willis method, were identified in the ferret, though with high parasite load for all agents.

The host with the highest occurrence of parasites was the possum (D. marsupialis), with: Ascaris sp. and Spirometra sp. helminths; Taenia sp., according to the HPJ; and eggs of Ancylostomatidae according to the Willis method.

As for protozoa, oocysts of Isospora sp. were observed in the three methods, and in enough quantity to be considered as a moderate degree of infection (242 oocysts/slide).

Diagnostic sensitivity analysis, based on direct fresh examination, showed the results in Table 1.
The relationship of the parasite load between helminths and protozoa associated to the classes of the animals can be seen in Table 2, as well as the statistical analyzes between helminthic and protozoonous parasitic load evaluated among the classes performed by the analysis of variance (ANOVA), two ways.

Comparison of the number of positive results for each method using the Bland-Altman graphical analysis showed little agreement between them, since the plots of differences by means of detections did not remain very close to the midline of the graph, as may be observed in Figures 1, 2 and 3.

These results corroborate other surveys (RONDON, 2010), identifying eggs and larvae of helminths and oocysts of Eimeria sp. in S. brasiliensis from two localities of the state of São Paulo.

The howler monkey (A. fusca) presented cysts of Giardia sp. identified only by direct method, coinciding also with studies by SILVA et al. (2009), who also verified the prevalence of Giardia and Cryptosporidium in monkeys held in captivity.

Other studies on capuchin monkey (S. apella) identified eggs of the Ancylostomatidae, Endolimax nana family and Balantidium coli cysts by the Willis method.

According to STUART; STRIER (1995) and KOUASSI et al. (2015), Ancylostoma and Strongyloide are the most commonly found helminths in primates; and PISSINATTI (2001) states that, in new world primates, parasitic diseases are the most prevalent findings at necropsies.

In the present study, it was observed that the direct and HPJ methods were more specific for the identification of parasites

Table 1. Sensitivity analysis of HPJ, Willis and direct techniques for faecal samples from wild animals.

\begin{tabular}{lcc} 
Technique & Sensitivity \% & Combined sensitivity* \% \\
\hline Direct & 89 & 29 \\
\hline HPJ & 67 & - \\
\hline Willis & 50 & - \\
\hline
\end{tabular}

*The combined sensitivity refers to the multiplication of percentages between techniques.

Table 2. Parasitic load (number of eggs or cysts / slide) by class of animals and analysis of ANOVA two factors between the classes.

\begin{tabular}{lccc} 
Class & $\begin{array}{c}\text { Parasitic } \\
\text { load } \\
\text { helminths }\end{array}$ & Parasiticloadprotozoa & Anova \\
Reptilia & 01 & 106 & $\begin{array}{c}\text { P Value: } \\
1,10\end{array}$ \\
\hline Aves & 02 & 112 & $\begin{array}{c}\text { P Valuecrít.: } \\
9,55\end{array}$ \\
\hline Mammalia & 82 & 456 & $\begin{array}{c}\text { P Value: } \\
\text { O,43* }\end{array}$ \\
\hline
\end{tabular}

*Although there was no significant difference between classes, the Tukey post hoc test was performed, inferring that there is a variation between Mammalia and birds and Mammalia and Reptilia, being the class that most presented infections by both protozoa and helminths. 


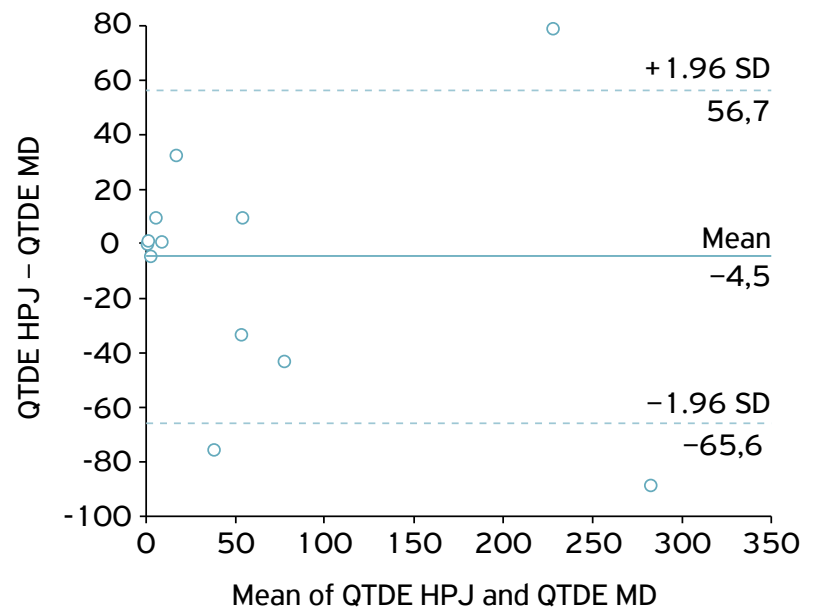

Figure 1. Joint comparison of all positive evaluations between direct (MD) and HPJ methods.

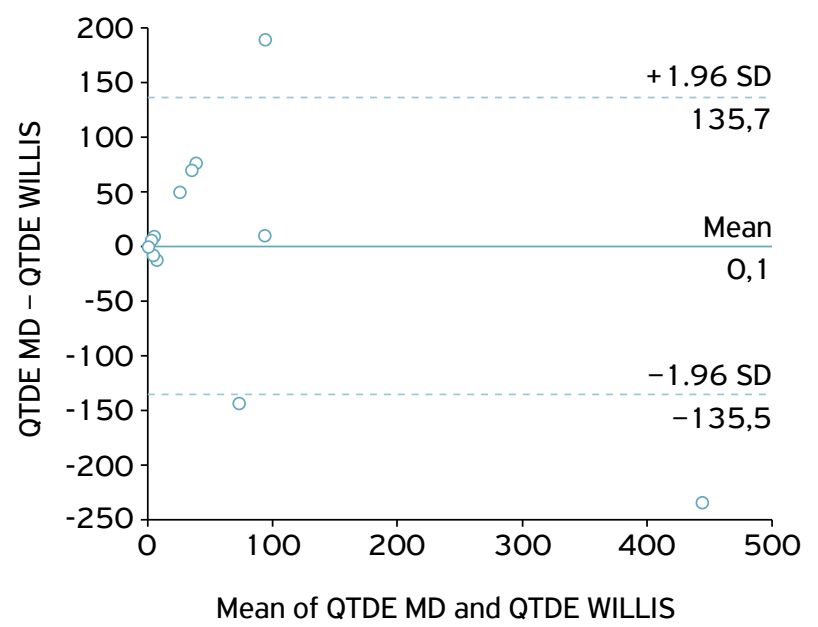

Figure 2. Joint comparison of all positive evaluations between direct (MD) and Willis.

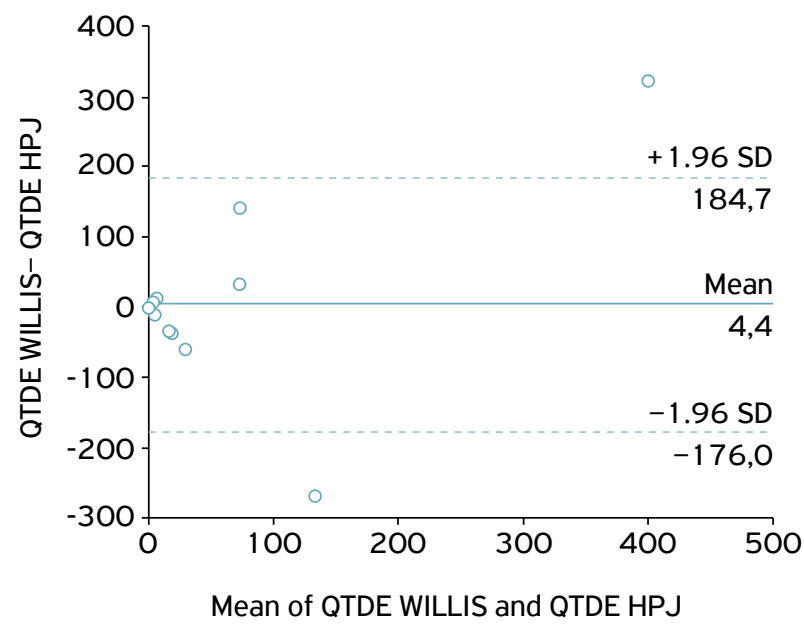

Figure 3. Joint comparison of all positive evaluations between HPJ and Willis methods.
(8/11 $-72.7 \%$ and $7 / 11-63.6 \%$, respectively). The Willis method presented lower positivity (36.4\%). These data are close to the results of MENDES et al. (2005), which identified positivity in the direct method with lugol at $69.2 \%$, Hoffman method at $73.3 \%$ and Willis method at $47.3 \%$.

With the data obtained in the present study, it can be observed that for both protozoa and helminths, the use of only one parasitological method is not sufficient to identify all the agents present in a fecal sample. Direct and HPJ methods proved to be effective in identifying intestinal parasites, but not all agents were identified simultaneously in both techniques, which leads to the conclusion that one technique complements the other. Therefore, the association of the direct and HPJ methods is best indicated to increase the probability of identifying intestinal parasites and to avoid false negative results.

According to MENDES et al. (2005), it would be important to carry out more than one diagnostic method in routine laboratories in order to detect parasitic forms of protozoa and helminths, especially when there is low parasitic load. The methods used proved to be a fast and inexpensive way to study cysts, oocysts, eggs and larvae of parasites, being a non-invasive and useful test for the study of parasites in wild animals.

More than $80 \%$ of the species studied were parasitized by protozoa and/or gastrointestinal helminths. These results evidenced the need to adopt protocols for antiparasitic treatment and control of endoparasites, as well as sanitary management of animals that live in captivity, especially mammals, which present a relevant prevalence with parasitic infections.

The behavior of the animals may influence parasitic contamination. Since they do not interact with animals of different species, a possible source of infection may be the access of other animals to the enclosure, such as rodents and free-living birds living in the surrounding region. Another problem may be the waste carried by handlers. Monkeys are extremely active and curious, and are constantly manipulating objects they find tending to have greater contact with their excreta, thus increasing the degree of contamination or recontamination.

When researching parasitic diseases, it is necessary to emphasize that most helminths are asymptomatic. In the case of wild animals, it must be considered that they did not present clinical signs of the diseases, since their feces had characteristics considered normal for the species. In this way, it is essential to emphasize the importance of performing periodic examinations of parasitic agents, using the most frequent parasite species, using the appropriate techniques. The Willis technique is not sensitive to protozoa, but only used as a comparative method application of any helminths present. Another point to be addressed is that even without clinical symptomatology, there should be surveys with a diversity of protoparasitological methods and that are done in a combined way, so as to have a better diagnostic accuracy, also evaluating the epidemiological profile of each animal to be surveyed, prevalence of parasite species and the techniques of better sensitivity. 


\section{REFERENCES}

BATISTA, A.M.B.; PEREIRA, M.A.V.C.; VITA, G.F.; BARBOSA, C.G.; ANTONIO, I.M.S.; BARROS, S.C.W.; MAGALHÃES, A.R.; FREITAS, J.P. Levantamento qualitativo de gêneros de parasitos em amostras fecais de jacarés criados comercialmente em sistema fechado no estado do Rio de Janeiro. Pesquisa Veterinária Brasileira, v.32, n. 10, p.1045-1049, 2012.

BLAND, J.M.; ALTMAN, D.G. Statistical methods for assessing agreement between two methods of clinical measurement. Lancet, v.1, n.8476, p.307-310, 1986.

BRANDÃO, M.L.; CHAME, M.; CORDEIRO, J.L.P.; CHAVES, S.A.M. Diversidade de helmintos intestinais em mamíferos silvestres e domésticos na Caatinga do Parque Nacional Serra da Capivara, Sudeste do Piauí, Brasil. Revista Brasileira de Parasitologia Veterinária, v.18, n.1, p.19-28, 2009.

BUNBURY, N.; JONES, C.G.; GREENWOOD, A.G.; BELL, D.J. Epidemiology and conservation implications of Trichomonas gallinae infection in the endangered Mauritian pink pigeon. Biological Conservation, v.141, n.1, p.153-161, 2008.

CATENACCI, L.S.; VELASTIN, G.O.; ROCHA, F.S. A fragmentação de habitat aumenta a intensidade de endoparasitas em gambás de orelhas brancas (Didelphis albiventris). In: CONGRESSO, 8., ENCONTRO DA ASSOCIAÇÃO BRASILEIRA DE VETERINÁRIOS DE ANIMAIS SILVESTRES, 13., 2004. Anais... Jaboticabal: ABRAVAS, 2004.

DE CARLI, G.A. Parasitologia clínica: seleção de métodos e técnicas de laboratório para o diagnóstico das parasitoses humanas. 2. ed. São Paulo: Atheneu, 2007. 810p.

FERRAZ, R.R.N.; NAMBA, T.K.; NIGRO, C.A.; RODRIGUES, F.S.M.; FORNARI, J.V.; BARNABÉ, A.S. Comparação entre os métodos de extração de metacercárias de Ascocotylesp (Trematoda: Digenea) dos tecidos de Mugil liza Valenciennes, 1836 (Teleostei: Mugilidae). Ciência Animal Brasileira, v. 15, n.3, p.354-361, 2014.

FLETCHER, R.; FLETCHER, H.; WAGNER, S.W. Epidemiologia Clínica: elementos essenciais. 3. ed. Porto Alegre: Artmed, 2003. 175p.

HOFFMAN, W.A.; PONS, J.A.; JANER, J.L. The sedimentationconcentration method in schistosomiasis mansoni. Journal Public Health and Tropical Medicine, v.9, p.283-298, 1934.

HUGGINS, D.W:; MEDEIROS, LB.; SIQUEIRA-BATISTA, R.; RAMOS JUNIOR, N.A. Diagnóstico laboratorial. In: HUGGINS, D.W.; SIQUEIRA-BATISTA, R.; MEDEIROS, L.B.; RAMOS JUNIOR, N.A. (Eds). Esquistossomose Mansoni. São Paulo: Grupo Editorial Moreira Jr., 1998. 75p.

KOBAYASHI, J.; HASEGAWA, H.; SOARES, E.C.; TOMA, H.; DACAL, A.R.; BRITO, M.C.; YAMANAKA, A.; FOLI, A.A.; SATO, Y. Studies on prevalence of Strongyloides infection in Holambra and Maceió, Brazil, by the agar plate faecal culture method. Revista do Instituto de Medicina Tropical de São Paulo, São Paulo, v.38, n.4, p.279-284, 1996.
KOUASSI, R.Y.W.; MCGRAW, S.W.; YAO, P.K.; ABOU-BACAR, A.; BRUNET, J.; PESSON, B.; BONFOH, B.; N'GORAN, E.K.; CANDOLFI, E. Diversity and prevalence of gastrointestinal parasites in seven non-human primates of the Taï National Park, Côte d'Ivoire. Parasite, v.22, p.1-12, 2015.

MENDES, C.R.; TEIXEIRA, A.T.L.S.; PEREIRA, R.A.T.; DIAS, L.C.S. Estudo comparativo entre os métodos de Kato-Kazt e coprotest. Revista da Sociedade Brasileira de Medicina Tropical, v.38, n.2, p. 178-180, 2005.

PINTO, R.M.; VICENTE, J.J.; NORONHA, D.; GONÇALVES, L.; GOMES, D.C. Helminth parasites of conventionally maintained laboratory mice. Memórias do Instituto Oswaldo Cruz, v.89, n.1, p.22-40, 1994.

PISSINATTI, A. Medicine, selected disorders. In: FOWLER, M.E.; CUBAS, Z.S. Biology medicine, and surgery of South America wild animals. Ames: lowa University Press, 2001.

RONDON, M.V.S.S. Biodiversidade de parasitas intestinais em mamíferos silvestres de duas localidades do Estado de São Paulo. Thesis (Doutorado em Parasitologia) - Universidade Estadual de Campinas, Campinas, 2010.

SANTOS, M.V.S. Levantamento de helmintos intestinais em bugio-ruivo, Alouatta guariba (Primates, Atelidae) na Mata Ribeirão Cachoeira, no Distrito de Souzas. Dissertation (Mestrado em Parasitologia) - Universidade Estadual de Campinas, Campinas, 2005.

SATO, Y.; KOBAYASHI, J.; TOMA, H.; SHIROMA, Y. Efficacy of stool examination for detection of Strongyloides infection. American Journal of Tropical Medicine Hygiene, v.53, n.3, p. 248-250, 1995.

SILVA, A.S.; GRESSLER, L.T.; LARA, V.M.; MONTEIRO, S.G.; CARREGAGARO, A.B. Protozoários gastrintestinais em bugios (Alouatta sp.) mantidos em cativeiro. Ciência Animal Brasileira, v.10, n.2, p. 669-672, 2009.

STUART, M.D.; STRIER, K.B. Primates and parasites: a case for a multidisciplinary approach. International Journal of Primatology, v.16, n.4, p.577-593, 1995.

STUART, M.D.; STRIER, K.B.; PIERBERG, S.M. A Coprological Survey of Parasites of Wild Muriquis, Brachyteles arachnoids, and Brown Howling Monkeys, Alouattafusca. Journal of the Helminthological Society of Washington, v.60, n.1, p.111-115, 1993.

SUDRÉ, A.P.; MACEDO, H.W.; PERALTA, R.H.S.; PERALTA, J.M. Diagnóstico da estrongiloidíase humana: importância e técnicas. Revista de Patologia Tropical, v.35, n.3, p.173-184, 2006.

WILLIS, H.H. A simple levitation method for the detection of hookworm ova. Medical Journal of Australia, v.8, p.375-376, 1921. 